\section{Two Cambridge cultures}

\section{William Cooper}

The Red and the Blue: Intelligence, Treason and the Universities.

By Andrew Sinclair. Weidenfeld \& Nicolson: 1986. Pp.179. £12.95.

To be published in the United States by Little, Brown.

I THOUGHT I couldn't bear to read another book about Burgess, Maclean et al. - or even a book in which they appeared as characters. I'm allergic to spies. SNEAKS ALL, I call them; regarding the CIA, $\mathrm{KGB}$ and MI5 as having more in common with each other than they have with the rest of us. As for the sneaks themselves, some of them are so eaten up with the vanity of sneakery that they can't resist sneaking for both sides at once! Vain and trivial people. Were the CIA, KGB and MI5 disbanded tomorrow, the difference in our world ten years hence would be insignificant.

Burgess, Maclean, Philby and Blunt appear throughout as characters in Andrew Sinclair's The Red and the Blue, to which he gives the more explanatory subtitle, "Intelligence, Treason and the Universities". I found I could read the book with admiration and approval. The universities in question are chiefly Cambridge and the period covered begins with the First World War and ends in the present day; the central feature of that period in Cambridge being the glorious era of physical discovery in the Cavendish Laboratory, discovery in atomic and nuclear physics which had a revolutionary impact on world history. The glory was at its peak in the years around 1932 - just when Burgess, Maclean, Philby and Blunt embarked on their private pettifogging tricks that have so hypnotized the British popular press. Mr Sinclair, however, judges his perspective on the whole Cambridge scene with a combination of independence, accuracy and understanding. (He took a double first in History at Trinity College, Cambridge.) His interpretation owes much to the concept of "The Two Cultures", first publicized by C.P. Snow in 1959 - which is when Mr Sinclair graduated, so he only arrived on the scene in person ten years after the half-way mark in his story.

From the end of the First World War to the beginning of the second, the scientific culture is epitomized, obviously, by the Cavendish Laboratory - Rutherford, Chadwick, Blackett, Cockcroft, Rutherford's remarkable Russian protégé, Kapitsa, and others. Kapitsa founded a very influential open club, where scientists could publicly exchange information about their discoveries. The literary culture is epitomized by a secret society called The Apostles, "a self-electing élite of those who considered themselves the brightest and best in contemporary literature and philosophy", its members drawn from the privileged classes, male and mostly from Eton, no scientists Keynes, G.E. Moore, Wittgenstein, E.M. Forster, Bertrand Russell and others. They were given to passionate mutual admiration; devotion to the growth of private virtues (in natural reaction against the collective madness of the earlier war); personal liberation in pursuit of beauty, love and truth — and furthermore, pursuit of beautiful young men, known to them in its platonic form as The Higher Sodomy... oh dear! It is a truth universally unacknowledged that extremely clever people can be ineffably silly: high intelligence is not automatically bonded with commonsense. The Apostles had their Bloomsbury offshoot, known as the Bloomsberries: Lytton Strachey, Leonard and Virginia Woolf, Clive Bell and Vanessa Bell and Duncan Grant, and others. Mr Sinclair takes his stand thus:

In terms of fundamental discoveries that would change our understanding of the structure of the world, the interchanges at the Kapitsa Club made the conversazione of the Society of the Apostles seem small beer. Science and technology derived from it would transform human societies, while the military application of atomic research would disturb international relations. Any political or social changes brought about by members of the Apostles could only be trivial. Yet the Apostles had the gift of the pen and the power of the word. They backed into publicity. Their clandestine doings became famous. Along with associates in Bloomsbury, rarely in the field of human endeavour has so much been written about so few who achieved so little. As for the Kapitsa Club, rarely in the field of human discovery has so little been written about so few who achieved so much.

In rebelling against the conventions of the past generation and looking inward with admiration upon themselves, the Society of the Apostles became vulnerable to invasion by Communism during the thirties, when the liberal-minded classes, if not some of the privileged classes, were very properly reacting against Nazism and Fascism. Burgess, Maclean, Philby and Blunt were Apostles converted to active Communism - a secret élite within a secret élite... Mr Sinclair traces their careers, through rightly being overt Soviet supporters when Russia was a major ally of the British during the war, to "moles" working their way, unvetted by virtue of
Apostolic cachet, incredibly into British Intelligence when the West reverted to anti-Communism and the Cold War. $\mathrm{Mr}$ Sinclair estimates the military damage they did as trivial, exceeded by the damage done by Fuchs and Pontecorvo, "whose actions only accelerated inevitable discoveries by months or the odd year". More serious was the damage they did to the course of research in those sciences that were of interest to the politicians and the military in prosecuting the Cold War and the armaments race.

Mr Sinclair takes the point that until the tide turned with the advent of war, research was "open", its findings publicly available without restriction: the absence of restriction was, and still is, regarded by scientists as essential to the speediest and most effective advance of their research. There was nothing secret about the discussions of the Kapitsa Club, and when Kapitsa was forcibly recalled to Russia in 1934 he took with him the common assumption that co-operation between his institute and the Cavendish would continue. That assumption was steadily eroded as the politicians and the military on both sides laid hands on nuclear physics; and it was in effect destroyed altogether in 1945 at the bombing of Hiroshima and Nagasaki: as Oliphant put it, "This has killed a beautiful subject". Mr Sinclair adds, "Fuchs's conviction on charges of espionage, followed by the defections of Burgess and Maclean, further soured the possibility of scientific collaboration. Espionage as usual had poisoned reciprocity. Treason was the enemy of reason." Well said! The story is a tragic one; the nature of science permanently marred by its use for unthinkable slaughter; human endeavour brought low by human weakness.

To end on a lighter note, let me earn my fee as a critic by finding fault. Occasional looseness in writing, for example "by months or the odd year". Occasional lapses of judgement, for example equating the damage of Fuchs and Pontecorvo - Fuchs actually was a nuclear physicist, whereas Pontecorvo's speciality was cosmic rays. Occasional failures in proofreading, for example "Sir Wallace Aken" was Sir Wallace Akers. For my taste too many names per inch of text - the index is a veritable list of All Thosc People You Would Like To Have Known But Never Had The Chance To Meet. And I began to feel that Mr Sinclair was tiring, his thinking becoming more dispersed, towards the end - when both cultures were themselves becoming more fragmented, more dispersed. Such fault-finding I simply dismiss in the face of the book's major achievement.

William Cooper, Savile Club, 69 Brook St, London WI, is the pseudonym of the novelist Harry Hoff. Methuen recently republished his book The Struggles of Albert Woods. 